\title{
Portrayal of Rohingya Women in the Newspapers of Bangladesh
}

\author{
By Md. Ragib Rahman \& Janifar Kamal Nova
}

State University of Bangladesh

Abstract- The study has been conducted to find out how Rohingya women are being portrayed in Bangladeshi newspapers. The Rohingya problem is one of the major problems in the world today. Naturally, Rohingya women are one of the biggest victims of this problem. The study has been conducted with several objectives such as getting an idea of how Rohingya women are being portrayed in the newspapers of Bangladesh, determining the relative rate of committing crime, vulnerability or success stories in the news reports about Rohingya women and gaining an idea of the socio-economic status of Rohingya women who came to Bangladesh as refugees from newspaper reports. The news items on Rohingya women have been analyzed in four leading newspapers in Bangladesh in terms of circulation. The news reports have been analyzed into three categories: crime, vulnerability and success. From the analyzed data we found that Bangladesh Pratidin, which has the largest circulation, published 72 news items regarding Rohingya women, Prothom Alo, the $2^{\text {nd }}$ largest circulated newspaper, published 37 news items, The Daily Jugantor published 76 news items and The Daily Star, the largest circulated English newspaper published 47 news items.

Keywords: rohingya women, newspaper, Bangladesh.

GJHSS-C Classification: FOR Code: 190301

Strictly as per the compliance and regulations of:

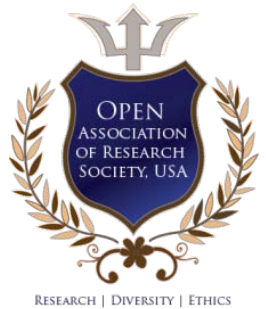

(C) 2020. Md. Ragib Rahman \& Janifar Kamal Nova. This is a research/review paper, distributed under the terms of the Creative Commons Attribution-Noncommercial 3.0 Unported License http://creativecommons.org/licenses/by-nc/3.0/), permitting all noncommercial use, distribution, and reproduction in any medium, provided the original work is properly cited. 


\title{
Portrayal of Rohingya Women in the Newspapers of Bangladesh
}

\author{
Md. Ragib Rahman ${ }^{\alpha} \&$ Janifar Kamal Nova ${ }^{\sigma}$
}

\begin{abstract}
The study has been conducted to find out how Rohingya women are being portrayed in Bangladeshi newspapers. The Rohingya problem is one of the major problems in the world today. Naturally, Rohingya women are one of the biggest victims of this problem. The study has been conducted with several objectives such as getting an idea of how Rohingya women are being portrayed in the newspapers of Bangladesh, determining the relative rate of committing crime, vulnerability or success stories in the news reports about Rohingya women and gaining an idea of the socioeconomic status of Rohingya women who came to Bangladesh as refugees from newspaper reports. The news items on Rohingya women have been analyzed in four leading newspapers in Bangladesh in terms of circulation. The news reports have been analyzed into three categories: crime, vulnerability and success. From the analyzed data we found that Bangladesh Pratidin, which has the largest circulation, published 72 news items regarding Rohingya women, Prothom $A / o$, the $2^{\text {nd }}$ largest circulated newspaper, published 37 news items, The Daily Jugantor published 76 news items and The Daily Star, the largest circulated English newspaper published 47 news items. The news stories published from the point of view of vulnerability of Rohingya women are about rape, women trafficking, forced marriage, health risk, involvement in prostitution, being victims of physical torture, death etc. On the other hand, the reports published from the point of view of crime of Rohingya women are about illegal immigration, passport forgery, drug dealing, theft, trying to create fake birth registration certificate etc. In contrast to these negative stories, the number of positive news report is very poor. Also, those articles highlighted some of the Rohingya women's achievements particularly, not a revolutionary change.

Keywords: rohingya women, newspaper, Bangladesh.
\end{abstract}

\section{INTRODUCTION}

T he media is called the 'mirror of society'. It is sometimes called the 'fourth pillar of the state'. It can play a strong role in setting the agenda of society. It even has the irresistible power with a view to drawing the attention of the international community to any important issue.

The Rohingya crisis is one of the most talkedabout issues in the world nowadays. They are called 'stateless people'. According to the United Nations, the Rohingya are one of the most persecuted minorities in the world (UN, 2013). Although this is an internal matter of Myanmar, they have entered Bangladesh as refugees at different times after being tortured in their own country. As a result, the Rohingya crisis now has a significant impact on the social, political and economic

Author a: State University of Bangladesh.

e-mail: ragibrahman.du@gmail.com life of Bangladesh. The Rohingya crisis is not a new issue in Bangladesh. But it has become complex since 2017. Different news about them have also been broadcast and published in different media at various times.

Women are a very significant part of the Rohingya population. In the context of the socioeconomic conditions of developing countries in the Third World, women are generally seen as neglected, abused and dependent on men (Chowdhury \& Jhuma, 2014). Needless to say, the situation of Rohingya women as a neglected and backward people is even more deplorable. At various times they have been the headlines of newspapers- sometimes as positive, sometimes as negative. Therefore, how the Rohingya women have been portrayed in the mainstream newspapers of Bangladesh will be explored through this research.

\section{Historical Background}

The Rohingya are a stateless Indo-Aryan people in the Rakhine state of western Myanmar. Most of the Rohingyas are followers of Islam and some of them are followers of Hinduism. The United Nations and Human Rights Watch have called the repression and torture of Myanmar's Rohingya 'Ethnic Cleansing' where evidence of crimes such as genocide has been found (UN, 2017a).

Until the annexation of Chittagong to the Mughal Empire in 1616, Arakan (Current Rakhine) and Chittagong was a separate independent state. Arakan remained an independent entity for more than a hundred years after the Mughals annexed Chittagong. In 1784, the Burmese king led a military campaign to capture Arakan. Since then Arakan has been a part of Burma. The Rohingyas think that the Arakanese are aggressors and deprivers of the freedom of the Rohingya community (Shikdar, 2018). So the onset of Rohingya grudge against the Burmese is very old.

There was coexistence between the Rohingya and the Burmese during the British rule. However, during World War II, the Japanese invaded Burma under British colonial rule. British were defeated and left power. This resulted in widespread clashes. Notable among these was the communal riots between the Buddhist Rakhine and the Muslim Rohingya. During the creation of India and Pakistan in 1947, the Rohingyas held several meetings with the Governor-General of 
Pakistan, Jinnah, and expressed their desire to remain with Pakistan. Other ethnic groups in Arakan could not accept this action. They considered the Rohingyas as 'unfaithful'. Jinnah, meanwhile, rejected the Rohingya's offer (Saha, 2017). Then the Rohingyas themselves formed the 'Rohingya Muslim Party' and started an armed struggle for the independence of Arakan and tried to carry out an armed rebellion against the government. When the military government came to power in Burma in 1982, the persecution of the Rohingya increased. In 1982, the Myanmar government revoked the citizenship of the Rohingya and officially labeled them 'infiltrators'. They were deprived of their right to vote, social and political rights in their own country (Myanmar Nationality Law, 1982).

Hundreds of thousands of Rohingyas were deported from Myanmar for the first time in 1977-78 and for the second time in 1990-91 and took shelter in Bangladesh. Then more and more Rohingyas started entering Bangladesh at different times. As of December 2017, about 7,00,000 Rohingya refugees took refuge in Bangladesh with a view to escaping the genocide that began on August 25, 2017 by Myanmar's military. In all, at least 11 lakh Rohingyas have taken refuge in Cox's Bazar at different times (Shikdar, 2018).

The first deadline for Rohingya repatriation was set for November 15, 2018. But at that time no one could be sent to Rakhine as the Rohingyas did not agree. The Myanmar government recently sent a list of 3,540 names from 1,033 families for repatriation. Despite ongoing repatriation efforts, the Rohingya have refused to return and are distributing leaflets demanding five points. The points are:

1. Rohingyas are natives of Arakan (Rakhine). That is why the law has to be passed in the parliament with the recognition of Rohingyas as 'local'.

2. Rohingyas living in Arakan State have to be given 'Citizen Card'. Also, Rohingya refugees living in Bangladesh and other parts of the world should be repatriated with citizenship cards and given the status of local citizens.

3. Rohingyas have to be taken back to their villages. Land confiscated from them should be returned to them with proper compensation.

4. UN peacekeepers must be deployed alongside Rohingya police to protect the lives and property of Rohingya in Arakan.

5. The perpetrators will have to be judged in the International Criminal Court instead of the local court in Myanmar (BBC News Bangla, 2019).

\section{ili. Objectives}

i. Getting an idea of how Rohingya women are being portrayed in the newspapers of Bangladesh.

ii. Determining the relative rate of committing crime, vulnerability or success stories in news about Rohingya women. iii. Gaining an idea of the socio-economic status of Rohingya women who came to Bangladesh as refugees from newspaper reports.

\section{Literature Review}

No direct work has been found on the portrayal of Rohingya women in the media during the Rohingya crisis. Therefore, some research articles that have been done on the representation of the Rohingya crisis in various international media have been reviewed here. At the same time, some research works on differences in the approach and frame of presenting the news stories in the media of different countries are also reviewed here.

Osama Kanaker, Mohamed Oklah Abughazli \& Mohd Faizal Kasmani (2020) in their study 'Media Framing of Minorities' Crisis: A Study on Aljazeera and $B B C$ News Coverage of the Rohingya' explained how framing theory has been implemented to discover the frames used by Aljazeera and BBC in framing the causes and ramifications of the Rohingya crisis. Two frames 'powerlessness' and 'responsibility' have been used to frame the selected news items. Both media presented the principal causes of this crisis which are security and military campaign whereas the prime ramification is deportation. Throughout the sample news reports, the struggle and sufferings of Rohingya were highlighted using the above mentioned frames, but the fundamental right of living in the region of Arakan was ignored. Rohingya people started to flee as they found no other way out, and these ramifications showed the powerlessness of Rohingya. On the one hand, 'responsibility' frame has been used while referring to politics and United Nations as two causes.

Md Khadimul Islam (2018) in his thesis titled 'How Newspapers In China, India \& Bangladesh Framed The Rohingya Crisis Of 2017' explored how the media in China, India and Bangladesh portrayed the Rohingya crisis from different perspectives in the light of normative theories. Analyzing 258 news reports from three different countries on the Rohingya issue, he found significant differences in the style of covering the issue by the media of China, India and Bangladesh. According to his analysis, the human interest and protest frame were emerged as the most important frame in Indian and Bangladeshi newspapers. In contrast, Chinese newspapers used the conflict and security frame most. Moreover, in Bangladesh, aid agencies appeared to be the most cited sources in newspapers, while in Indian newspapers, national officials were cited most. In Chinese newspapers, the Myanmar government appeared on top of the list of sources used.

Similarly, Mumtahin Awny (2019) in her research titled 'The Rohingya refugee issue: Differences in media framing in Bangladesh and India' compared the Rohingya crisis in the news reports published in 
Bangladeshi and Indian newspapers categorizing the reports in a few frames such as victim frame, intruder frame, responsibility frame, administrative frame and return home frame. After her analysis, she concluded that Bangladeshi newspapers are more likely to use the victim frame while Indian newspapers are more likely to use the intruder frame. This study also found that Bangladeshi newspapers more often feature refugees, spokespersons for NGOs and other media/journalist as sources, while Indian newspapers more often feature their domestic officials as sources. These two research articles are very effective in understanding how the portrayal of the same event in the media may differ in the light of the economic, social and political conditions of a country.

Ma Y, Pan Z, Yu F, Shi $Y$ and Siu $Y Y$ in their 'Constructing Rohingya Identity: An Analysis of Media Process and Self Representations' tried to present the whole issue from three different perspectives - the western mainstream media, Rohingya activists and a Rohingya family. The common denominator from all perspectives is that they were portrayed as poor and stateless. However, researchers have expressed the view that the image portrayed in the media is somewhat one-sided. After analyzing the reports from the western mainstream media, the researchers said that the representations of Rohingyas were shaped and depicted as impoverished, stateless, and inhumanely treated. They were tagged as 'the most persecuted people in the world'. On the other hand, in most cases, the general Rohingya people feel confused about the cause of their current situation and the attitude of the Myanmar government. Through the interviews with a Rohingya family, the researchers came to know that they were optimistic and having strong hope for their future. Moreover, while some news and reports described Rohingyas as extremists, Rohingyas themselves did not want to have violence and fights but peace and equality. They would like to stay in their motherland and fight for their identity and recognition. We find some similar facts in Kunnawut Boonreak's (2008) research article 'Beyond Merely Impoverishment: Representation of Rohingya in Thailand through Alternative Media'. While analyzing the representation of Rohingya, Boonreak investigated how alternative media in Thailand represented Rohingya. Mainstream Media showed one-sided story by portraying Rohingya as a group that faces statelessness, impoverishment and inhuman treatment. But there is another side of the coin where Rohingya people expressed optimism for a better future and desire to live a peaceful life in their motherland and it had been upholding by two alternative media named White Channel and Amnesty International Thailand. These representations were not emphasized or shown in the mainstream media, but they were also the representations of Rohingyas. So these two articles are also relevant to my research.

Zarqa S. Ali (2014), in his research titled 'Visual representation of gender in flood coverage of Pakistani print media' highlighted gender representation in the visual news coverage of the 2010 floods in Pakistan. He said that media often represents women as victims to gain their own interest. The researcher observed that the print media flood coverage showed gender stereotypes such as men as leaders with women being dependent, men as active and women as passive, women as weak and emotional while men are strong both physically and emotionally etc. He pointed out some clear explanations of why Pakistani media represented women as dependent and subordinated while women had a great role in facing that crisis. He found the politics of sympathy, sexiest stereotype, commodification of pain of the female and economic interest of media were the main reasons behind it. The research is very relevant to find out how the media portrays women in crisis during a disaster and how gender affects there.

\section{Theoretical Framework}

The following two theories will be used in this research:

a) Representation Theory: Representation refers to the use of language to convey meaning to the world. This language can be photography, film, literature, painting etc. Stuart Hall, known as a cultural theorist in the United Kingdom, provided this theory. The meaning of anything is actually created through representation. Because meaning does not exist in the object. It is manufactured and produced. There are three approaches to explain how meaning is represented through language. They are Reflective approach, Intentional approach and Constructional approach. How Rohingya women are being portrayed in Bangladeshi newspapers will be analyzed in this research through the theory. It will show how media represents a positive, negative or neutral outlook on Rohingya women.

b) Framing theory: The conception of framing was first propounded by Gregory Bateson in 1972. The framing process contains media packages and presentation of information to the public. The media enlightens certain events and then turns them into a particular context of words to encourage or discourage certain notions. Thus, the media focuses on people's point of view of reality. The Media selects the contents they want to let people know and decides how they will be portrayed to a common person. What kind of frame has been used to portray Rohingya women in Bangladeshi newspapers will be explored here through this theory. 


\section{Vi. Methodology}

The content analysis method will be used here for data collection in this research. The content of the news items published about the Rohingya women in the newspapers of Bangladesh will be analyzed. The news reports will be categorized into three categories: success, crime and vulnerability.

The first four newspapers of Bangladesh in terms of circulation (Both in Bengali \& English language) will be selected as samples in this research. These newspapers are: Bangladesh Pratidin, Prothom Alo, The Daily Jugantor and The Daily Star (Bangladesh Film and Publication Department, 2019) Three of these newspapers are published in Bengali language and one in English language. All the news items related to Rohingya women published in these newspapers during the time of the emergence of the Rohingya crisis in Bangladesh (from September, 2017 to October, 2019) will be selected as sample.

\section{Presentation and Analysis of Information}

\begin{tabular}{|l|l|l|}
\hline \multicolumn{2}{|c|}{ Name of Newspaper: Bangladesh Pratidin } \\
\hline \multicolumn{1}{|c|}{ Total news report: 72} & Vulnerability: 30 (42\%) \\
\hline Success: 01 (1\%) & \multicolumn{1}{|c|}{ Crime: 41 (57\%) } & $>$ Death \\
\hline Success in personal life & $>$ Illegal immigration & $>$ Forced marriage \\
& $>$ Passport forgery & $>$ Health risk \\
& $>$ Theft & $>$ Involvement in prostitution \\
& $>$ Trying to create fake birth registration certificate & $>$ Rape \\
& $>$ Yabba (drug) dealing & $>$ Victims of physical torture \\
& $>$ Women trafficking
\end{tabular}

We can see from the table above, a total of 72 news items on Rohingya women were found in the Bangladesh Pratidin newspaper within the stipulated time mentioned in the sample.

Of the 72 reports, 41 (57\%) were related to crimes committed by Rohingya women. These crimes include illegal immigration, passport forgery, drug transactions, theft, fake birth certificates etc. Out of the total 16 news items published on illegal immigration, nine news items showed that Rohingyas were detained from different places on their way to Malaysia by the sea illegally and one of them was detained from the airport. The rest of the news reports also mention that Rohingyas were detained at different times from Rajshahi, Narsingdi and India's Tripura border. According to these reports, most of the detained Rohingyas are women. According to their information, they had planned to go there illegally by sea in the hope of getting married and settling in Malaysia. According to police, the main target of the dealers is unmarried Rohingya women. Married women are being taken to Malaysia by showing the temptation of marriage. Besides, we found 12 news reports on passport fraud. According to most reports, the arrested criminals were caught from Hazrat Shahjalal International Airport. Apart from this, some similar incidents had taken place in Manikganj, Benapole border, Barisal, Khulna and Bogra.
Rohingya women are on the list of crimes with involvement in drugs. A total of 12 reports were found in this regard where Rohingya women were directly involved in drug trafficking. Apart from this, some reports reported that Rohingya women were arrested for stealing and for trying to create fake birth certificates.

On the other hand, 30 news reports (42\%) have expressed the vulnerability of Rohingya women. Some of these news items are about the rape of Rohingya women. A news report published on August 24, 2019, was titled "Rape of Rohingya with the intention of genocide in Myanmar: UN". The report cites the United Nations as saying that Myanmar's military raped and sexually abused Rohingya women and children in 2017 with the intention of genocide to eliminate the Muslim minority. The report further states that 80 percent of rapes were intentional. The Myanmar army is responsible for 82 percent of all gang rapes. A report published on September 23, 2017, was titled "Armies are raping women by entering the house in the dark of night". According to this report, women who were sexually abused are unable to seek medical care for the fear of public embarrassment. A report published on October 6, 2017, shows the arrest of a local political leader for trying to rape a Rohingya woman in Ukhia. Four news items cover the rescue of Rohingya women during their trafficking to Malaysia. We found 10 news 
reports each containing news of the death of one or more Rohingya women. In most cases, they drowned at sea. In some cases, Rohingya women died due to local quarrels. In addition, there were some reports regarding the health risks of Rohingya women. The title of the report published on May 26, 2018, was "Secretly serving unmarried mothers and rape victims". According to the report, out of millions of pregnant women, 20 percent were victims of sexual violence in Myanmar. A huge part of the victims were children and unmarried girls. The Rohingya people were in dire straits with these unmarried pregnant women. Other headlines on their health risks included "More than 50,000 Rohingya women are pregnant and breastfeeding", "Two Rohingyas infected with HIV in hospital", "Hundreds of Rohingya women give birth in Nomansland" etc. In addition, four news reports have mentioned that Rohingya women are involved in prostitution. After escaping from the camp, they are getting involved in various immoral activities and prostitution. A report published on August 29, 2018, was titled "Locals' marriages with Rohingya girls are on the rise". According to the report, marriage rates among local youth and Rohingya women have increased in Cox's Bazar, Rangamati, Khagrachhari and Bandarban. Therefore, local administration issued special warning in this regard.

In contrast to these negative news reports, only one news item has the context of the success of Rohingya women. The report, published on October 19, 2019, was titled "Jasmine, a young Bangladeshi woman on the list of the most influential women in the world". The news is that Jasmine, a young Rohingya girl, was included in the list of 100 most inspiring and influential women in the world published by the British media BBC. She has been able to change her destiny with great difficulty. Although this is a personal achievement of a Rohingya woman, not of the entire Rohingya women's community.

\begin{tabular}{|c|c|c|}
\hline \multicolumn{3}{|c|}{ Name of Newspaper: Prothom Alo } \\
\hline \multicolumn{3}{|c|}{ Total news report: 37} \\
\hline Success: 02 (6\%) & Crime: $16(43 \%)$ & Vulnerability: 19 (51\%) \\
\hline$>$ Success in personal life & $\begin{array}{l}>\text { Illegal immigration } \\
>\text { Passport forgery } \\
>\text { Physically assault } \\
>\text { Trying to create fake NID } \\
>\text { Yabba (drug) dealing }\end{array}$ & $\begin{array}{ll}> & \text { Death } \\
> & \text { Forced marriage } \\
> & \text { Health risk } \\
> & \text { Involvement in prostitution } \\
> & \text { Rape } \\
> & \text { Victims of physical torture } \\
> & \text { Women trafficking }\end{array}$ \\
\hline
\end{tabular}

The table mentioned above shows that we found a total of 37 articles on Rohingya women in the period specified in the sample in 'Prothom Alo'. In terms of news numbers, this number is less than the news published in 'Bangladesh Pratidin'. 16 (43\%) news reports are related to Rohingya women's crimes. These crimes included illegal immigration, passport forgery, Yabba drug transactions, assaults, making fake NIDs etc.

Out of the total five news items published on illegal immigration, three of them show that Rohingya women were detained from different places on their way to Malaysia by sea illegally and in one article they were detained from the airport while going to Kuwait. In addition, a news item highlighted the interviews of six Rohingya women who fled to Bangladesh from India. According to the information obtained from the detained women, there is a demand for Rohingya women in the marriage market in Malaysia. Because a part of the country's labor market is occupied by the Rohingya youth of Myanmar. There is a shortage of Rohingya women compared to Rohingya men.

Besides, a total of five news items were published on passport fraud. These incidents took place at some places in Bangladesh such as Chittagong, Kurigram, Mymensingh and Manikganj. The report raises issues such as the arrest of suspects and misinformation of names and identities. Another report found the direct involvement of Rohingya women in drug trafficking. Apart from this, the news of the arrest of a Rohingya woman and her husband for attacking a police officer also found a place in the pages of the newspaper. Four news reports related to fake NID were published. A Rohingya woman who visited her husband in Saudi Arab more than once using a Bangladeshi 
passport was arrested in Chittagong district election office with NID as she went to collect her smart card.

On the other hand, 19 news outlets (51\%) highlighted the vulnerability of Rohingya women. Among these news reports, four were about the rape of Rohingya women. A news report published on May 2, 2018, was titled "How many children are going to be born in Rohingya camps?" According to the report, everyone in the Rakhine state knows that when the military attacks they go from house to house and rape women; a woman confessed to being raped twice and became pregnant. The report further stated that as of February 25, 2018, around 224 pregnant women were treated. On September 24, 2017, a news item reported that the United Nations received evidence of 'being raped' of Rohingya women. A total of 25 rape victims said members of Myanmar's military were responsible for this heinous act. On October 10, 2017, a news item titled "Life of Rohingya Women" was published. According to that report, women fled to the camps to save their lives, but the situation in the refugee camps was not conducive for women. Several women inside the camp complained of sexual harassment.

On January 09, 2018, the news titled "Teenager girls are housebound in their own camps" presented the issue of women's safety. According to the report, one million Rohingyas were living in Bangladesh back then. $53 \%$ of them were women. $54 \%$ of them were under 18 years of age. Two news outlets were reported on the rescue of Rohingya women during their trafficking to Malaysia. The issue of Rohingya women's health risks came up in 5 news. The report, published on 24 September 2017, was titled "Focus on Women Refugees". According to the report, Rohingya women and adolescents could be provided with such "dignity kits' so that they can protect their own privacy during periods. If condoms could be distributed among men for birth control, then it is much more logical to distribute free sanitary pads among women. There was also a headline in other published news report about health risks, "Crying for water". Two news items were published on child birth and health security. In addition, other articles were on Rohingya women's involvement in prostitution. The report mentioned incidents of being picked up on the way from Myanmar to Bangladesh. One news reported the death of more than one Rohingya woman. The death occurred at sea in a boat sinking. In September 23, 2017, a report was published "A Rohingya woman was tortured". It was about a Rohingya woman who was brutally tortured in Maungdaw, Rakhine, Myanmar. "Rohingya women cried and made others cry", it was about Rohingya women breaking down in tears as they were describing genocide, gang rape and child murder in the report, which was published on February 28, 2018. A report was published about Rohingya camps' growing social problems which are related to women on August 26, 2018.

Amidst of these negative news reports, only two news items upheld the success of Rohingya women. First one is already mentioned above which title was "Bangladeshi young lady Jasmine in the list of influential women in the world". Another report, published on May 20, 2018, titled, "Rohingya women are becoming caliphs to change fortunes in Cox's Bazar". They earn money by sewing clothes at home. Forty-five Rohingya women were given sewing training in two batches every day at the shelter. Although it is a success story, the amount of positive news is legibly low.

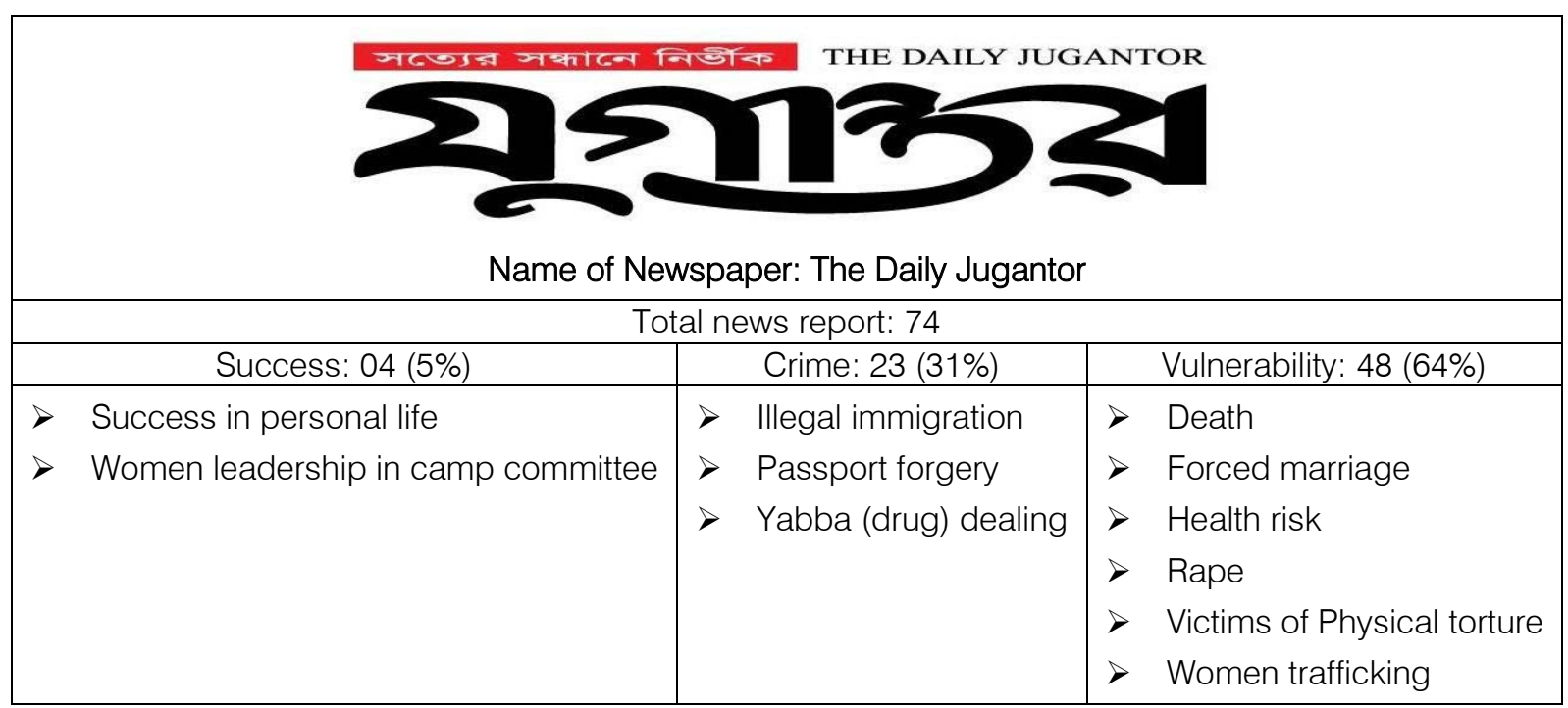

We can see here that out of the total 76 news items received from The Daily Jugantor during the period mentioned, 48 news items (64\%) focused on the vulnerability of Rohingya women, 23 news items (31\%) focused on their crime and four news items (5\%) focused on their success.

This newspaper has published the most 48 (64\%) news reports on the vulnerability of Rohingya 
women. There are 14 reports on trafficking of women, nine reports on physical torture of Rohingya women and nine reports on deaths of Rohingya women.

We found seven news reports on rape in this newspaper with great importance. The headlines translated into English are as follows, "70,000 pregnant Rohingya women seek refuge in Bangladesh", "Rohingya women gang-raped in Rakhine are being divorced", "Rohingya women have been gang-raped by the Myanmar army", "Suu Kyi avoided the issue of rape of Rohingyas" etc. The headline of a report published on May 1, 2018, was "Rohingya mothers who have been raped give birth to children". There, Human Rights Watch cited a survey that found that two-thirds of women were victims of sexual violence but did not report it to authorities or charities. They did this in fear of shame and stigma. The headline of the report published on December 11, 2017, was, "AP's investigative report: Myanmar army's rape of Rohingya is arbitrary and planned". According to an investigative report of AP, the Rohingya women were raped sometimes in front of their husbands, and sometimes after their husbands and children were killed. The AP reporter also came to know about the incidents of inserting gun barrels into the vaginas of Rohingya women before and after the rape. The report was based on separate interviews with 29 Rohingya women in refugee camps in Bangladesh. The number of women who were raped has surprised the AP's reporter. However, the AP did not respond to a request from the Myanmar army for comment. Earlier, three separate investigations by the United Nations and the two British media outlets, the BBC and the Guardian, revealed a similar reality.
The report, published on February 2, 2019, was titled, "I have to be shot here before I can be sent to Myanmar," the raped woman told Angelina (Angelina Jolie, special envoy of the United Nations High Commissioner for Refugees and a Hollywood actress, visited the Rohingya camp in Cox's Bazar). The issue of health risks for Rohingya women was also highlighted in various news outlets. At various times, the headlines of this reports were "Rohingya women and children are at extreme health risk", "Two Rohingya women infected with HIV admitted to hospital", "30,000 women are waiting for the delivery of children in Rohingya camps", "Rohingyas are not interested in birth control" etc.

On the other hand, out of 23 news stories on crime, 21 news stories were about illegal immigration and passport forgery. There were also reports of Rohingya women being detained while carrying drugs.

In contrast to the negative news items of Rohingya women, four positive news items were published. Among them were "Bangladeshi cricketer of Rohingya descent in list of 100 most influential women" and "Rohingya woman elected head of asylum camp" which were discussed in previous newspapers. Two more success stories had been added. The news item titled "Razia Sultana Receives Brave Woman Award of America" was based on the nomination of Razia Sultana, a lawyer and human rights activist born in Maungdaw, Rakhine State, Myanmar. Also, another story was found on January 9, 2019, under the headline "The story of a Rohingya girl going to university from a refugee camp".

\begin{tabular}{|c|c|c|}
\hline \multicolumn{3}{|c|}{ Name of Newspaper: The Daily Star } \\
\hline \multicolumn{3}{|c|}{ Total news report: 47} \\
\hline Success: 05 (10\%) & Crime: 10 (22\%) & Vulnerability: 32 (68\%) \\
\hline $\begin{array}{l}>\text { Ceasing of child marriage } \\
>\text { Success } \\
>\text { Women leadership in camp } \\
\text { committee } \\
>\text { Women's training }\end{array}$ & $\begin{array}{l}>\text { Illegal immigration } \\
>\text { Passport forgery } \\
>\text { Yabba (drug) dealing }\end{array}$ & $\begin{array}{l}>\text { Distress } \\
>\text { Health risk } \\
>\text { Rape } \\
>\text { Victims of physical torture } \\
>\text { Women trafficking }\end{array}$ \\
\hline
\end{tabular}

The Daily Star published a total of 47 reports on Rohingya women in the sample period. Of these, 32 $(68 \%)$ cases were about the vulnerability of Rohingya women.

Among these, 14 news items were on the rape of Rohingya women. News published on December 12, 2017, was titled "Nightmare in Rakhine". The report described 21 women's and girls' stories who were raped. A 13-year-old girl was raped in front of her brothers, a wife was raped after the husband and child had been killed. A pregnant woman was raped. When the military set their house on fire, the husband and the children escaped but she could not and got raped afterward. After being raped, there were incidents like 
walking naked in the field and so on. There was an article titled "Myanmar troops' sexual violence against Rohingyas 'genocidal intent': UN report" published on August 22, 2019. The report stated that hundreds of Rohingya women and girls were raped, with 80 percent of the rapes corroborated by the Mission being gang rapes. The Tatmadaw (Myanmar military) was responsible for 82 percent of these gang rapes. It indicated that the military intended to destroy the Muslim ethnic minority. Another story titled "Licence to rape" published on December 13, 2017, stated about women being raped by Myanmar military. There are many more news titles regarding women being raped such as, "How much more evidence is needed?", "Myanmar troops committed mass rape of women", "Raped, killed because they are Rohingya", "Rape alarm for Rohingya women" and so on. The issue of Rohingya women's health risks came up in 8 news item. News published on September 12, 2018, titled "Rohingya Refugees: Women face risk of abuse, health issues" stated that Rohingya women were facing health problems due to unsafe and unsuitable facilities of refugee camps. The report titled "Rohingya women, children still at acute risk: Unicef" represented the shortage of water, sanitation and hygiene facilities in the refugee camps. It was published on October 23, 2017. There was another story on Rohingya women's health especially the new mothers. "Rohingya refugee crisis: Family Planning: Too important, yet ignored" published on November 03, 2017, showed the challenges of health problems, family planning and suggestions. In the report titled "Over 16,000 Rohingya women are pregnant: Health minister" showed that more than 16 thousand Rohingya women were pregnant and according to health minister. They were under treatment at camps. Report published on September 17, 2017 , titled "Water, Sanitation Crisis: Roadside refugees suffer the brunt" upheld the unsafety of going to nearby jungle for evacuating as there is no latrine and no facilities for women's bathing in camp. Women were giving birth to children and both mother and children were not getting any health facilities. UN Women prepared a report with testimonies 51 percent of the displaced people were women and girls. They live in terrible conditions and lack adequate food, water, sanitation, medical care and access to their livelihoods and assets in the news titled "Rohingya refugee crisis: Almost everyone is survivor or witness" published on October 31, 2017. There were two more news items titled "Birth Control: Rohingyas lack awareness", and "Focus on Rohingya women's health". There were six news reports which represented the clear distress of women. The news titled "The uncertain fate of Rohingya" showed women are the targets for trafficking, raping, sexual harassment and there is no hope of getting proper safety. The report "what hope is there for Rohingya women and children?" published on September 23, 2017, stated that women were dying due to lack of treatment and their children were becoming alone. There was no proper arrangement and security for women. Other news reports were "Violence at Home, Insecurity Here, Uncertainty Ahead", "No Woman's Land", "Polygamy in the CAMPS", "Hiding from traffickers in 'prison-like' tents, Rohingya girls dream of school" etc. There were two news items on women trafficking and one news item on physical torture.

$10(22 \%)$ were related to their crime. A total of five articles were published on passport fraud and was already mentioned in Prothom Alo and Bangladesh Protidin. Four articles were published on women's drug dealing. One article was about illegal immigration.

On the other hand, there were five success stories about Rohingya women which included leadership and training. There was an article of remarkable achievement titled "Rohingya refugees elect women leaders in camp committee polls: UNHCR" published on June 28,2018 . According to this news, in the first camp committee election they elected 12 leaders in which half of them were women. A story about a volunteer Rohingya woman titled "For the good of the community" published on June 22, 2019, who went home to home and spread the lifesaving message. There was an article about Rohingya women's training titled "Providing refugee women, girls with life skills" published on March 05, 2019. This report stated that as Rohingya women and girls had very opportunities to become self-dependent, the UN launched a project to provide Rohingya women and teenage girls with life skills and vocational training in the camp. There was another success story titled "Let Rohingya women decide their future: Amnesty". It was about a mother and a daughter tailoring in camp to become independent. Another one was "Child Marriage of Rohingya girl stopped in Malaysia" published on March 08, 2019. 
The following is a summary of news reports from four newspapers:

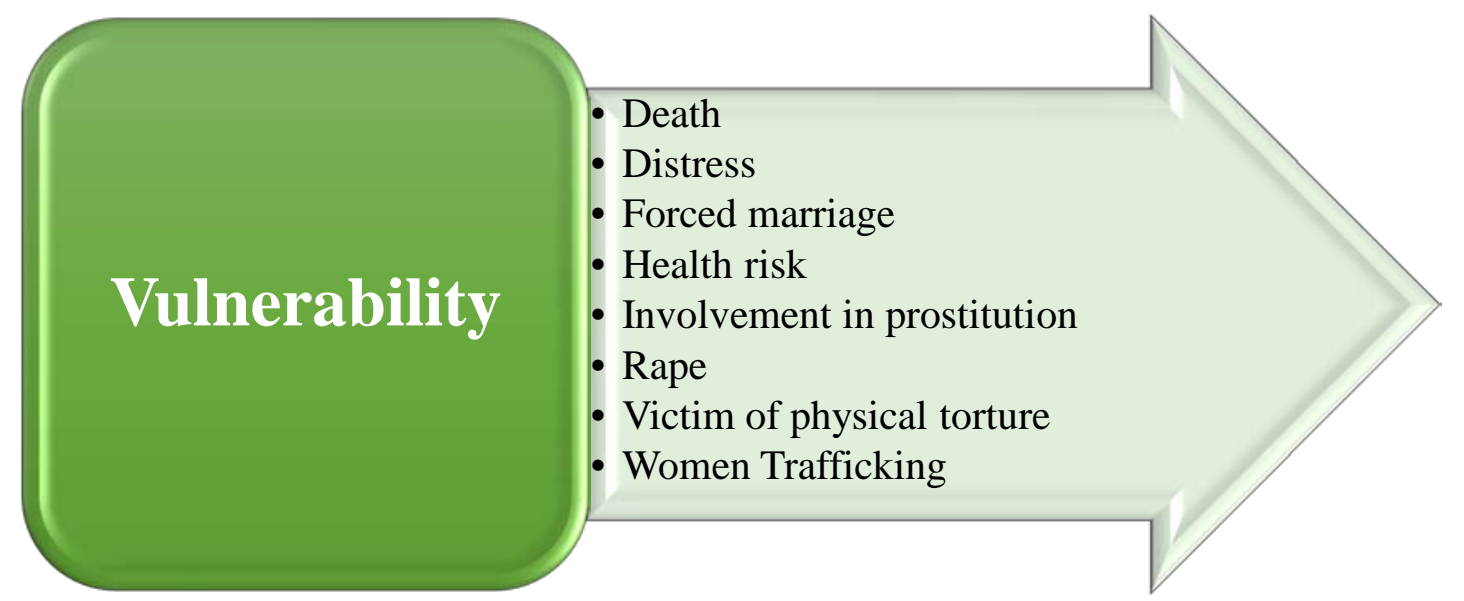

- Illegal immigration

- Passport forgery

Crime

- Physically assault

- Theft

- Trying to create fake birth registration certificate

- Yabba (drug) dealing

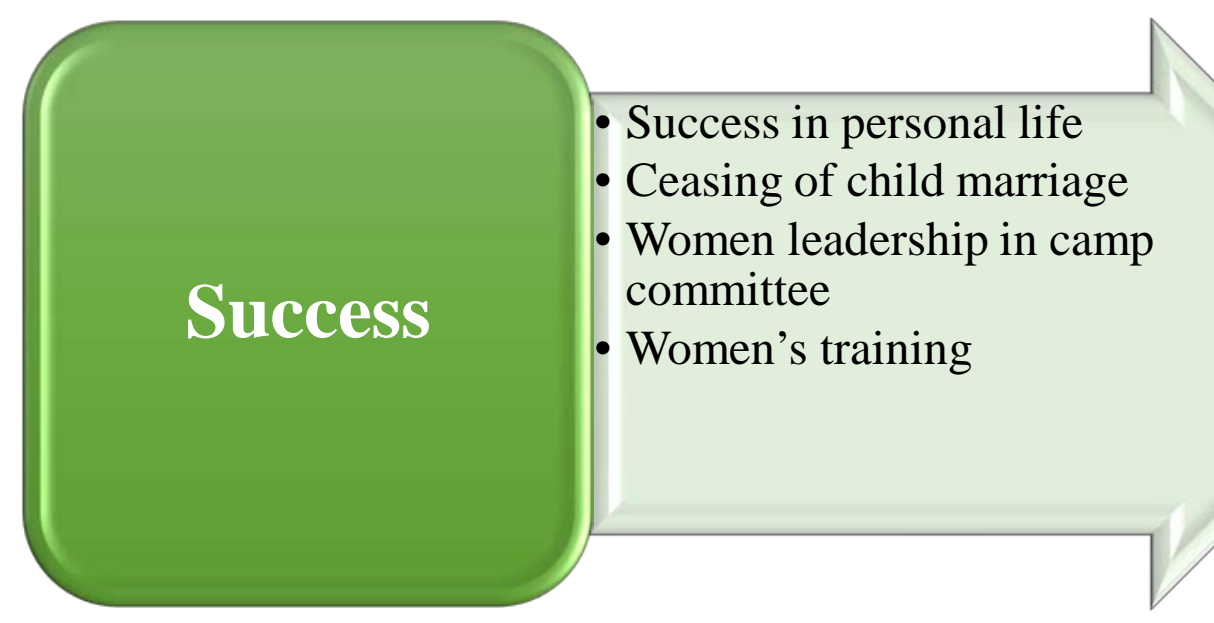




\section{CONCLUSION}

\section{Portrayal of Rohingya women in Bangladeshi newspapers}

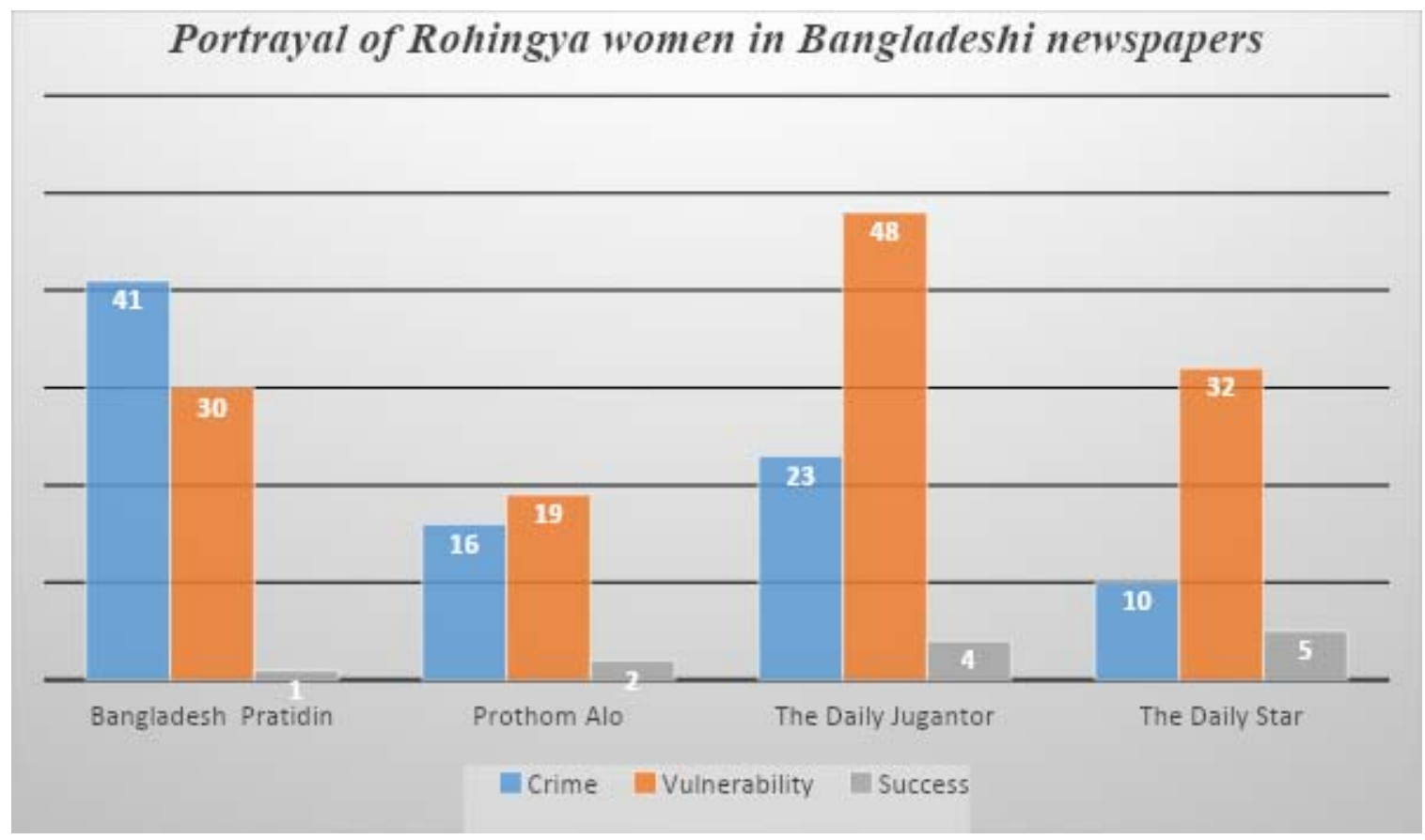

\section{Chart: Comparative rate of news reports on Rohingya women in various newspapers}

The content analysis of this study shows that all of these newspapers upheld the helplessness of Rohingya women and acceptance of their fate. The fourth pillar of state created the standard of women's reaction during a humanitarian crisis, which is being vulnerable and not doing anything for changing their fate. Through the Framing Theory, we can see that all these newspapers framed women in that way they wanted to present women and spread the news. Bangladesh Pratidin, which has the largest circulation in Bangladesh, published 72 news reports regarding Rohingya women, whereas the $2^{\text {nd }}$ largest circulated newspaper Prothom Alo published only 37 news items, The Daily Jugantor published 76 news items and The Daily Star, the largest circulated English newspaper in Bangladesh, published 47 reports. The Daily Star and The Daily Jugantor published five news items regarding Rohingya women's success or stepping on the path to better days. On the other hand, Prothom Alo and Bangladesh Pratidin published three and one reports respectively. These news stories are much less than other news stories, which are regarding rape and crime. Most of the news item of these newspapers were about Rohingya women's being raped, caught while fleeing Malaysia and smuggling drug etc. The amount of news report about health risks is very low which is one of the major problems of the camp.

Through the Representation Theory, we can say that Prothom Alo comparatively seemed to be very sensitive while writing about Rohingya women amidst these newspapers. Besides The Daily Star tried to represent women's suffering which might be sympathy politics. (Hankins, 2019). On the other hand, Bangladesh Protidin tended to represent the crime of Rohingya women. Every newspaper mentioned about Myanmar military being responsible for rape, sexual violence of Rohingya women. But there was no news report on Rohingya women's fundamental rights which should have been there as common people are dependent on newspaper to know about the Rohingya issue.

\section{References Références Referencias}

1. Ali, Zarqa S (2014). Visual representation of gender in flood coverage of Pakistani print media. Weather and Climate Extremes, 4, 35-49.

2. Awny, Mumtahin (2019). The Rohingya refugee issue: Differences in media framing in Bangladesh and India. Graduate Theses and Dissertations. 17639.

3. BBC News Bangla (August 20, 2019). Rohingya songkot: ze pachti dabi puron hole Myanmar e fire zete raji soronarthira (Rohingya Crisis: The refugees agreed to return to Myanmar if the 5 demands are met) [Retrieved from https://www.bbc.com/bengali/ news-49403487]

4. Boonreak, K. (2018). Beyond Merely Impoverishment: Representation of Rohingya in Thailand through Alternative Media. JOURNAL OF THE INTERNATIONAL CENTER FOR CULTURAL RESOURCE STUDIES, 4, 41-62. 
5. Chowdhury, S. S. \& Jhuma, J. F. (2014). Humayun

Ahmeder colocchitro: Prosongo gender songbendoshilota (Films of Humayun Ahmed: Gender Sensitivity in Context). Dhaka: Social Science Journal Volume 8.

6. Hankins J. (2019). Living together: Sympathy and the practice of politics. Anthropological Theory, 19(1), 170-190.

7. Haq, F. (2007). Representation. Dhaka: Zogazog Volume 8.

8. Islam, Md Khadimul (2018). How Newspapers In China, India And Bangladesh Framed The Rohingya Crisis Of 2017. Electronic Theses and Dissertations. 648.

9. Kanakar, Osman; Abughazli, Mohamed Oklah \& Kasmani, Mohd Faizal (2020). Media Framing of Minorities' Crisis: A Study on Aljazeera and BBC News Coverage of the Rohingya. Jurnal Komunikasi: Malaysian Journal of Communication, $36(2), 1-16$.

10. Karim, A. K. M. R. (2017). Rohinya somossa o somadhan (Rohinhya Crisis \& Solution). [Retrieved from http://m.u71news.com/article/99467/index. $\mathrm{html}]$

11. Ma Y, Pan Z, Yu F, Shi Y, et al. (2018). Constructing Rohingya Identity: An Analysis of Media Process and Self-Representations. Global Media Journal 2018, 16:31.

12. Saha, S. K. (2017). Rohingya songkot o ekti nirmoho bisleshon proceshta (The Rohingya crisis and a desperate analysis effort). [Retrieved from https:// blog.bdnews24.com/sukantaks/224949]

13. Shikdar, A. K. M. A. (2018). Rohingya songkot o Bangladesh - otit bortoman vobisshot (Rohingya Crisis \& Bangladesh-Past, Present, Future) [Retrieved from https://www.bd-pratidin.com/ editorial/2018/09/03/357444]

14. UN News. (Septermer 11, 2017). UN human rights chief points to 'textbook example of ethnic cleansing' in Myanmar. [Retrieved from http://www. un.org/apps/news/story.asp?NewsID =57490\#. WilY J0qnG71] 